\title{
Discussion on Funny Athletics Games in Physical Education of Female College Students
}

\author{
Ali Yu \\ College of Physical Education, Jiangxi Science and Technology Normal University, Nanchang, 330013, China
}

Keywords: Funny athletics games, female college students, physical education.

\begin{abstract}
Today people live in the world depending on their look and IQ. People's physical fitness seems to be declining. College students, a group that has most free time and has generally higher IQ. Many of these people are simple-minded and have strong limbs. While girl college students account for a large part. The girls are a natural group of people who do not love sports and female college students have a little amount of exercise. Although college students have a lot of time, but not many people are willing to put their time on sports, on the athletics. Is it caused by improper teaching method or inadequate enthusiasm? This paper revolves around this issue.
\end{abstract}

\section{Introduction}

Athletics includes not only a straight run but also includes athletics all-round movement, which is composed of a number of items such as running, jumping, throwing. Athletics competition is composed of field race, track race, road running, walking and cross-country running, and also includes "Decathlon" that is composed of part of race and track items, which shows the diversity of athletics. Athletics also has individuality, in addition to relay race; the other items do not need teammates. You can complete the individual activities by yourself; athletics is accessible for all people. You can participate in and carry out the event you want. Athletics has universality, which can be carried out regardless of streets or alleys and it does not need a special sports venues. Funny athletics games are a little more entertaining, ornamental and less formal compared to athletics. Funny athletics games are divided into several kinds: 1 . ground relay running, 2. obstacles relay running, 3. personal funny race, 4. double funny race. If athletics is the test and exercise to the physical quality, then the funny athletics is more inclined to the human body balance and the speed of response and so on. During the university, we have a lot of time, only for a small number of time every day we are learning, then we should learn what to do, with the rapid development of science and technology, female college students are faced with employment pressure, serious impact on female college students Of the mental health, this situation if not resolved as soon as possible may lead to psychological sense of inferiority and self-confidence, this time need to give the right sports activities to guide, it is clear that with a strong entertainment and ornamental fun track is preferred. But most of the female college students do not like sports, this in the end is our own problem or physical education problem? Through our survey results show that female college students generally expressed their own reasons, most female college students after entering the university lost the original high school that kind of momentum, there is no high school that kind of fighting spirit, because most of the school physical education It is only perfunctory, so we have not put the physical exercise on the heart, this paper around the fun athletics in the female college students to explore the teaching of physical education, from female college students, fun track and sports teaching to discuss. 


\section{The history and meaning of funny athletics games}

\section{The history of the development of funny athletics games}

In 3500 BC, the first ancient Olympic Games were held in the ancient Greek Olympic village. At that time, there is only one item sprint, and later gradually added long jump, high jump, long-distance running and other items. These items brought more fun for athletics. China's athletics began in the early 20th century, which was brought by foreign missionaries. At that time the games were only held between the church schools. Until the beginning of the founding of new China, athletics began popular in the country and people's technical level improved quickly. Athletics is divided into field, track and all-around. China has a more comprehensive development for all aspects, and we have also made good results.

Funny athletics was developed because people found formal athletics is too formal and rigorous, which was dedicated to the entertainment before official game. Its purpose is to bring people laugh, let people more interested in watching the official game. Of course, it also needs to record results, on the sub-points up and down. Funny athletics is divided into three parts: 1. running, 2. jumping. 3. throwing. China in the university to promote the fun athletics sports is based on the psychological characteristics of our college students, the use of sports games interesting features to attract more college students Engaged in athletics exercise. In the near future, the fun athletics movement will be accepted by the rest of the world with its high training value, interesting value and intense competitive value. Funny athletics has the following advantages compared to the formal games:

a. Can reflect the athletics training and education functions;

b. Can reflect the athletics game puzzle fitness function;

c. Can reflect the athletics games to promote the development of individual psychological function;

d. Can reflect the athletics function of athletics;

e. Can reflect the fun of athletics games

We can also through the fun track to cultivate and improve their athletic ability and activity interest, thereby enhancing their physical and health.

\section{The meaning of funny athletics games}

The real athletics can really enhance people's physical agility, exercise people's will, to make people become faster, higher and stronger. And funny athletics cannot be effective on this aspect. It is mainly to bring people laughter, bring entertainment before formal competition, so that people can better watch the official games. It can exercise athletes' limb coordination and balance, but also stimulate their passion and love for athletics, but also to add a lot of fun for their boring college life, to increase their enthusiasm and vitality in the class. Promoting funny athletics is not just our choice, but also the choice of history. Funny athletics can lay a good foundation for our body, can cultivate the interest and hobbies to athletics, and can cultivate a good psychological basis for us. Because the teaching philosophy of funny athletics is roughly same with the new curriculum standard, it has been recognized by the teachers. There are specialized training equipment to facilitate the activities carried out to help stimulate the interest of students, and the requirements of the venue is very small, easy to carry out the activities and implementation. The funny athletic games are more suitable for students' physical and mental development, but also conducive to shaping the students' mental characteristics and lifelong sports awareness.

\section{The Summary of the History and Meaning of Funny Athletics Games' Development}

Athletics is very popular in China, and we also have made many compelling achievements in a variety of world-class competitions. Funny athletics developed later than formal games, but now it is developing rapidly. Why? Because the entertainment, randomness and popularity make it easy to accept and appears in the streets. In the school, the athletics after the guidance of the new curriculum, for different teaching objects, the formation of a different sports characteristics, more suitable for 
girls to participate, not only improve the girls' physical fitness and exercise level, but also greatly improve the class Classroom efficiency and quality, to stimulate the interest of students in sports, to help students correct the attitude of physical exercise and the correct learning objectives.

\section{Physical Education of Female College Students}

\section{Female college students}

University is a degenerate paradise. It is like a cotton candy, which is easy to come in but hard to go outside. In the college, there are many people who do not take learning seriously. Female college students just want to make them more beautiful, but few of them can think of going to exercise. Female college students in the university are modern and energetic intellectual groups and the most active and creative part of the young people. But after a series of surveys, we found that $80 \%$ of the girls had only physical activity Stay in the surface of awareness, more than $90 \%$ of female college students daily physical exercise no more than half an hour, these cold numbers reflect the female college students on the understanding of physical exercise is still relatively low. Female college students are a group of people want to improve the "wisdom of the United States" groups, but I think they should be natural beauty, physical beauty and "wisdom of the United States" together to show the unique beauty of female college students, only physical exercise to better their own beauty, Only to learn the United States, the perfect blend of temperament beauty in order to emit a true female college students atmosphere, temperament and vitality.

\section{Physical education}

Physical education is instruction in the development and care of the body ranging from simple callisthenic exercises to a course of study providing training in hygiene, gymnastics, and the performance and management of athletic games. Physical education is also the basic form of school sports to achieve, is one of the ways to implement the objectives of sports, physical education this activity has long appeared before, in this half a century the rapid development of modern social conditions, physical education because of social conditions. The development of the rapid development. On the one hand, the improvement of social conditions, so that people's living standards improve, to provide people with a lot of free time, so that people have more opportunities for physical exercise, physical exercise requires physical education, indirectly led to the development of physical education, On the other hand, the development of modern science and technology, heavy industry, to provide more sports equipment, but also led to the development of physical education. Physical education is a kind of internal and external fitness system embodies the physical development of the order and comprehensiveness.

Order refers to the performance of the body in the form of physical development of the "order" and the development of the main organs of the "order" on.

Comprehensiveness refers to the process of physical education is to enhance the students' physical fitness and improve their health level. It not only has the ability to make students energetic and successfully complete the learning tasks, but also has a long-term basis for laying the foundation of life, longevity and improving national quality. Efficiency, which is the use of physical education and significance lies.

\section{Physical Education of Female College Students}

There are very few femal college students who like sports. Is it caused by the female college students themselves, or some reasons of physical education? Through the survey, we found the main problem stands at the female college students themselves. Their own learning enthusiasm is not high, but also less active in physical exercise, but also because the school's teaching philosophy falls behind and the teaching facilities are incomplete, and then lead to their enthusiasm for the funny athletics down. 


\section{Conclusions}

Because most of the female college students are rarely involved in these athletics games, but compared to the formal athletics, funny athletics games has a lot of differences. First of all it is different from the official athletics, followed by it has strong entertainment and ornamental, and it does not have so high requirements as formal athletics. Funny athletics games can give their college life a beautiful color, exercise their body, enhance their physical agility and will, but also allow them to become better. So I think it is a good idea to develop funny athletics games in female college students, through which we can mobilize the enthusiasm of everyone's movement, but also it can play a substantial exercise role, but also bring everyone on the enthusiasm of physical education. Funny athletics games have a lot of room for development in female college students.

Through the survey I suggest that in the teaching of funny athletics games, we shall take into account the differences between students' technical level and physical quality, use individualized and practical teaching methods; in the funny athletics class, students are very easy to perform improper movement because they pay too much emphasis on team performance and personal performance. They may ignore the correctness of the movement, and the instructor shall pay attention to correct and correct guidance in the teaching process. It is recommended that the school to establish a systematic, complete and scientific teaching system, to enrich the contents of athletics, and provide a complete funny athletics facilities, in order to facilitate better and faster promotion and popularization of athletics.

\section{References}

[1]Li Ruxin,et al. Theoretical Analysis and Experimental Research on funny athletics teaching. Journal of Xiangnan University,2004(4).

[2]Feng Chuancheng.Reflections on the Teaching Reform of athletics under the New Curriculum Standard. Journal of Wuhan Institute of Physical Education, 2005(10).

[3]Hu Xiaoming. New Century Sports to Entertainment and Health. Sports and Science, 2001, 22(4):42-48. 